УДК 669.013

\title{
СУЧАСНИЙ СТАН ТА ПЕРСПЕКТИВИ РОЗВИТКУ ПІДПРИЄМСТВ МЕТАЛУРГІЙНОЇ ГАЛУЗІ УКРАЇНИ
}

\author{
Муиникова С.А., к.е.н., доцент (НМетАУ)
}

В роботі проведено кількісний аналіз функціонування підприємств металургійної галузі України в сучасних економічних умовах. Визначено пріоритетні напрями діяльності та види металургійної продукиї. Визначено місие та роль металургії в загальному внутрішньому та зовнішньому товарообороті. Зосереджено увагу на проблемах функиіонування підприємств металургійної галузі в промисловому комплексі країни. Пропоновані пропозичії щуодо виходу металургійної галузі національної економіки з кризових умов господарювання.

Ключові слова: чорна металургія, металурzійне піоприємство, аналіз діяльності, обсяги реалізації, експортні пріоритети.

\section{СОВРЕМЕННОЕ СОСТОЯНИЕ И ПЕРСПЕКТИВЫ РАЗВИТИЯ ПРЕДПРИЯТИЙ МЕТАЛЛУРГИЧЕСКОЙ ОТРАСЛИ УКРАИНЫ}

\author{
Муиникова С.А., к.э.н., доц., доцент (НМетАУ)
}

В работе проведен количественный анализ функиионирования металлургической отрасли Украины в современных экономических условиях. Определены приоритетные направления деятельности и виды металлургической продукиии. Определено место и роль металлургии в общем внутреннем и внешнем товарообороте. Внимание сосредоточено на проблемах функиионирования металлургической отрасли в промышленном комплексе страны. Внесены предложения по выходу металлургической отрасли национальной экономики из кризисных условий хозяйствования.

Ключевые слова: черная металлургия, металлургическое предприятие, анализ деятельности, объемы реализации, экспортные приоритеты.

\section{CURRENT STATE AND PROSPECTS FOR THE DEVELOPMENT OF METALLURGICAL ENTERPRISES OF UKRAINE}

\author{
Mushnykova_S.A,_Candidate of Economic Sciences, Associate Professor \\ (National Metallurgical Academy of Ukraine)
}

The article analyzes the activities of the metallurgical industry. He showed a significant impact on the entire industrial complex of Ukraine. The current state of the world market indicates global reductions in demand for steel products. In these conditions, domestic metallurgical producers also function. Along with an increase in the volume of sales of metal products on the domestic market, a decrease in the share of export products is observed. The reasons for this were: a decrease in the level of competitiveness of domestic metal products, an increase in their prices and the emergence of new powerful competitors in the world market: China, India and South Korea.

But, we believe that for the further development of the metallurgical industry, it is necessary: refusal or reduction in sales of semi-finished products and raw materials and the 
transition to the export of metal products with a high share of added value; the search for new global markets for metal products; advanced training of workers employed in the operational activities of metallurgical enterprises and raising the level of labor motivation; obtaining new tax and budget benefits by domestic metallurgical enterprises.

Keywords. ferrous metallurgy, metallurgical enterprise, activity analysis, sales volumes, export priorities.

Постановка проблеми. Останні майже тридцять років економіка України пройшла шлях від отримання радянської спадщини, у вигляді розвинутою індустріалізації, до ринкових умов господарювання 3 класичним проявом їх ознак: втратою керованості підприємств, розривом економічних зв'язків між колишніми споживачами та металургами України, дефіцитом обігових коштів в наслідок інфляції та неплатежів, згортанням бюджетного фінансування, тиском потужних конкурентів на внутрішньому і зовнішньому ринках, - що в кінцевому випадку призвело до погіршення фінансово-економічних показників і різкого скорочення темпів зростання металургійного виробництва.

Сучасний же стан соціальноекономічних відносин в країні має ознаки постіндустріальної держави. Незважаючи на це, металургія залишається одним 3 лідерів виробництва промислової продукції. Так, частка металургії у ВВП країни становить близько $38 \%$, у промисловому виробництві - 27,3\%, експорті - 34,2\% [1]. В Україні існує значний науково-дослідний потенціал щодо розвитку металургійного виробництва.

Аналіз останніх досліджень i публікацій. Станом та перспективами розвитку металургійної галузі промислового комплексу країни зацікавлені науковці та практики такі, як: Козенков Д.С.[2], Кулицький С.[3], Хижняк О.С.[4] та багато ін. Аналіз сучасного стану окремих підприємств чорної металургії та в загалі галузі проводиться вченими та практиками спираючись на офіційні дані Державної статистики України у відповідність часу та ситуації що склалася [1] та світової спільноти [5].

Виділення невирішених частин загальної проблеми. Але, на сьогодні $\epsilon$ проблеми в чорній металургії, які пов'язані 3 подальшим зниженням якості продукції, втратами ринків збуту через зниження рівня конкурентоспроможності цілих підприємств, недостатнім рівнем інноваційності як окремих підприємств чорної металургії, так й галузі в цілому, зниженням рівня державної фінансової підтримки розвитку та ін. Ряд проблем, які виникають у функціонуванні цілої галузі промислового комплексу країни, потребують, перш за все, ретельного аналізу відповідно до ситуації що склалася у відповідний часовий період.

Метою роботи $є$ проведення аналізу сучасного стану чорної металургії та виявлення перспектив іï розвитку в подальшому.

\section{Виклад основного матеріалу} дослідження. Металургійна галузь промисловості $\epsilon$ найбільш старою та розвиненою галуззю на сьогодні в Україні. Більш стрімкого розвитку металургія набула в 50-70-ти роки XX сторіччя під час всебічної індустріалізації народного господарства. Після здобуття незалежності Україна успадкувала від колишнього СРСР потужний гірничо-металургійний комплекс, який за своїми масштабами становив понад $35 \%$ колишнього загальносоюзного гірничо-металургійного комплексу. Але, наслідками затяжної фінансово-економічної кризи 1991-1995 pp., стали скорочення внутрішнього попиту, втрата обсягів виробництва основних видів металопродукції: чавуну, сталі, прокату, - практично вдвічі. Проте, бажання вижити в ринкових умовах, що 
тільки формуються, переорієнтувала чорну металургію на експорт.

Сьогодні

підприємства

металургійної галузі виявилися не готовими до всіх викликів, пов'язаних зі світовою кризою, насамперед надвиробництвом чорних металів, падінням попиту на металопродукцію низької якості, посиленням конкуренції й появою нових гравців на світових ринках: Китаю, Індії й Південної Кореї [3]. Крім того, роками накопичувалися системні проблеми, пов'язані 3 необхідністю технічного й технологічного переоснащення виробництва, поліпшення якості чорних металів, випуску нових видів сталі й прокату. Металургійні підприємства України в порівнянні 3 розвинутими країнами миру характеризуються істотним технологічним відставанням і підвищеною енергоємністю. Їхнє устаткування сильно зношене, а технології морально застаріли [3].
Незважаючи на вищесказане, у 2018 році країна посідала 11 місце за обсягом виробництва сталі і 3 місце - за обсягом експорту металопродукції та $є$ одним 3 лідерів серед країн-виробників чорних металів у світі. Металургія України входить до десятки найбільших виробників i експортерів металу. Понад $80 \%$ металопродукції експортується до країн Європи, Азії, Близького Сходу, Південної Америки [1, 5] (табл. 1). 3 таблиці 1 можна побачити певну зміну в реалізації металопродукції на експорт протягом 8 місяців 2018 - 8 місяців 2019 років. Загальна сума реалізації знизилася за визначений період на 10,07\%. Значне погіршення показників відбулося за рахунок зниження обсягів реалізації чавуну та брухту чорних металів $-31,11 \%$ та -89,55\% відповідно. Але в цілому, можна стверджувати про незначне коливання обсягів реалізації металопродукції на експорт.

Таблиия 1

Вартість реалізаиії металопродукиії підприємсть металургійної галузі на експорт, млн. дол. США [1]

\begin{tabular}{|l|c|c|c|}
\hline \multicolumn{1}{|c|}{ Продукція } & 8 міс. 2018 & 8 міс. 2019 & $\begin{array}{c}\text { Зміна, \% } \\
2019 / 2018\end{array}$ \\
\hline Сировинні матеріали, в т.ч.: & 1534,4 & 1190,38 & $-22,42$ \\
\hline чавун & 737,3 & 507,94 & $-31,11$ \\
\hline феросплави & 696,9 & 668,05 & $-4,14$ \\
\hline брухт чорних металів & 98,2 & 10,26 & $-89,55$ \\
\hline інші сировинні матеріали & 1,9 & 4,11 & 116,32 \\
\hline Напівфабрикати & 2166,5 & 2069,03 & $-4,50$ \\
\hline Прокат, в т.ч.: & 3248 & 2989,6 & $-7,96$ \\
\hline Труби сталеві & 484,6 & 475,7 & $-1,84$ \\
\hline Металовироби & 99,19 & 93,51 & $-5,73$ \\
\hline Всього & 6948,9 & 6249,01 & $-10,07$ \\
\hline
\end{tabular}

На сьогодні гірничо-металургійний комплекс України є повною технологічною системою, що складається з підприємств 3 видобутку і переробки залізорудної сировини, виробництва коксу i феросплавів, виплавки чавуна i сталі, а також 3 підприємств 3 виробництва прокату.
Гірничо-металургійний комплекс України включає: 15 металургійних комбінатів i заводів, на частку яких припадає близько $98 \%$ національного виробництва сталі і 100\% виробництва передільного чавуну; 3 феросплавних заводи; 14 гірничодобувних підприємств; 12 коксохімічних заводів; 13 заводів 3 
виробництва вогнетривів; 20 метизних заводів; 8 підприємств 3 виробництва труб i 134 підприємства, що організували виробництво труб. Узагальнюючу характеристику структури гірничометалургійного комплексу України можна представити у вигляді схеми (рис 1). Підприємства гірничо-металургійного комплексу України постачають на світовий ринок: залізорудну сировину, у тому числі концентрат, окатиші і кускову руду, феросплави, чавун, напівфабрикати (квадратну заготовку, сляби, трубну заготовку), готовий прокат, в тому числі плоский гарячекатаний і холоднокатаний прокат в рулонах i листах, рейки, арматурну сталь i катанку, профільний прокат, а також вироби подальшого переділу - сталеві труби, металовироби, прокат з покриттями та ін.

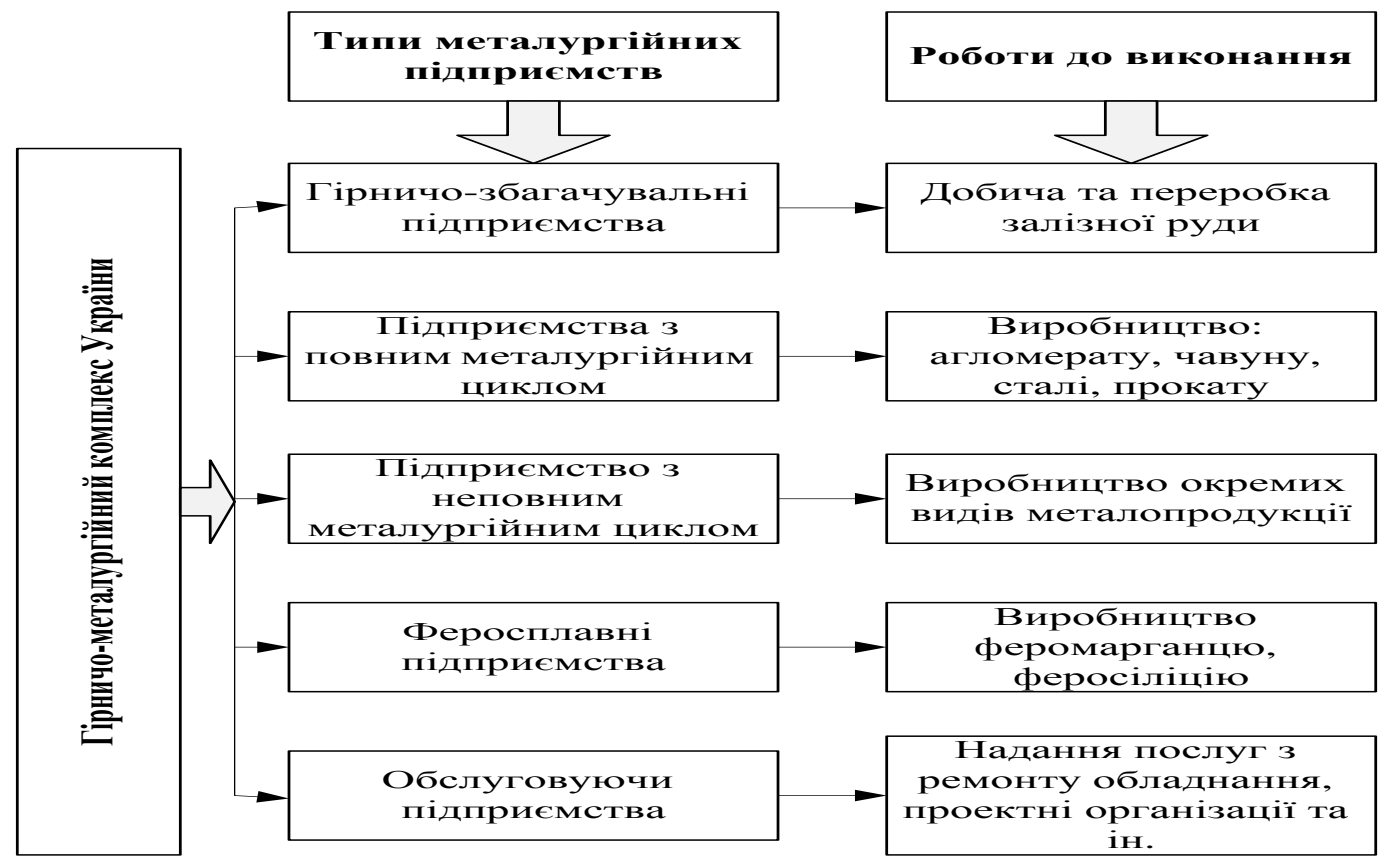

Рис. 1. Узагальнена характеристика підприємств гірничо-металургійного комплексу України

Протягом останніх п'яти років реалізації металопродукції на спостерігається значне збільшення внутрішньому ринку (табл. 2, рис. 2).

Таблиия 2

Виробництвво та реалізація металопродукиії підприємств металургійної галузі (внутрішній ринок), млн. грн. [1]

\begin{tabular}{|l|c|c|c|c|c|}
\hline & 2014 & 2015 & 2016 & 2017 & 2018 \\
\hline $\begin{array}{l}\text { Металургійне } \\
\text { виробництво }\end{array}$ & 208524,2 & 125567,5 & 125009,4 & 354584,7 & 418210,3 \\
\hline $\begin{array}{l}\text { Виробництво чавуну, сталі } \\
\text { та феросплавів }\end{array}$ & 173309,9 & 104255,5 & 106868,3 & 296972,1 & 345303,1 \\
\hline $\begin{array}{l}\text { Виробництво труб, } \\
\text { порожнистих профілів і } \\
\text { фітингів зі сталі }\end{array}$ & 18738 & 10169,9 & 7478,6 & 25289,6 & 33054,4 \\
\hline $\begin{array}{l}\text { Виробництво пршої } \\
\text { продукції первинного } \\
\text { оброблення сталі }\end{array}$ & 4810,1 & 2479 & 3025,6 & 9407,7 & 10495,3 \\
\hline
\end{tabular}




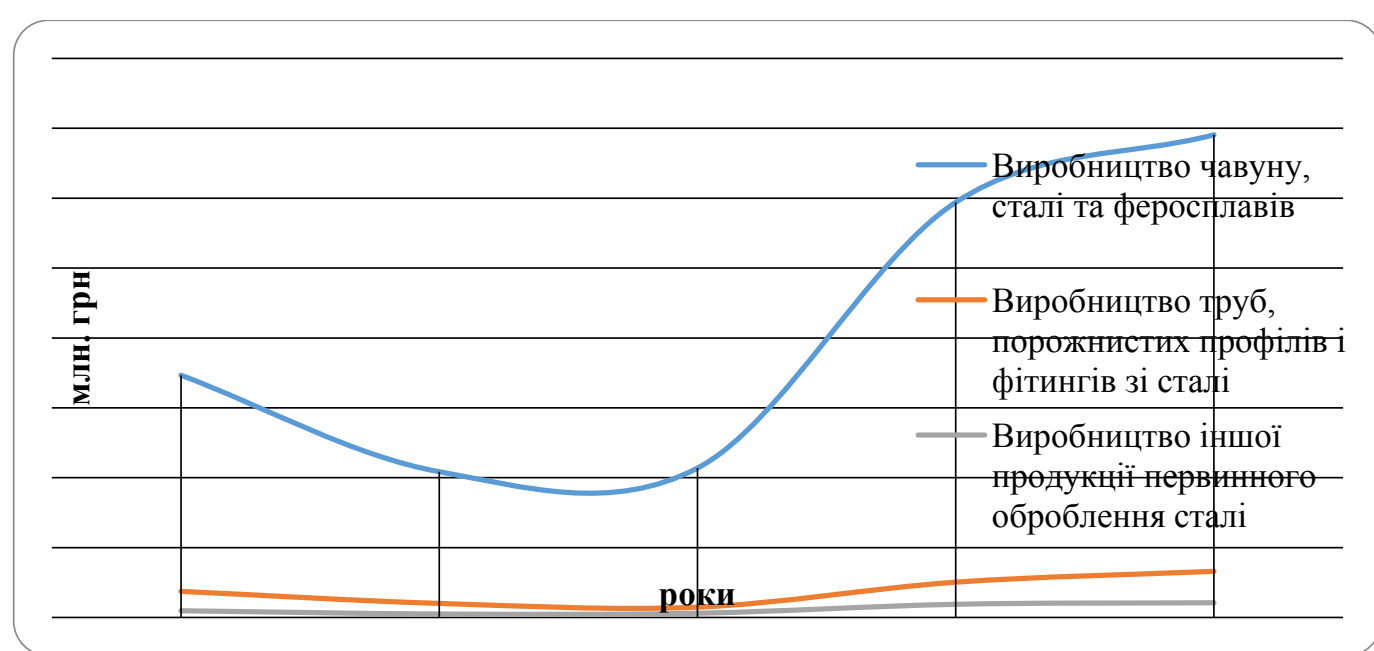

Рис. 2. Виробництво металопродукиії підприємств металургійної галузі за 20142018 p.p. [1]

За результатами представленими в табл. 2 та рис. 2 можна спостерігати, що 3 2014 по 2018 р.р. обсяги металургійного виробництва збільшилися практично вдвічі: 3 208524,2 млн. грн. до 418210,3 млн. грн. На такі зміни, в більшості, вплинуло зростання обсягів виробництва та реалізації чавуну, сталі та феросплавів. Так, якщо в 2015-16 p.p. спостерігається зниження рівня реалізації металопродукції, то в 2017-18 p.p. - стрімке збільшення цієї продукції до 345303,1 млн. грн. Виробництво прокату практично не змінилося протягом останніх п'яти років.

Загалом можна визначити вплив діяльності металургійної галузі в промисловому комплексі України (табл. 3).
Частка металургії в загальному обсязі реалізованої промислової продукції протягом 2014-2018 p.p. складає в середньому $16 \%$. Причому частка металургії в загальному обсязі товарного експорту коливається від 23,4\% до 28,3\%. При зниженні середньооблікової кількості працівників задіяних в металургійній галузі з 272 тис. осіб до 190 тис. осіб все ж таки спостерігається зростання обсягів прямих іноземних інвестицій. Але, частка металургійних підприємств, які займалися інноваційною діяльністю протягом періоду, що аналізується залишається незначною і складає в середньому $17 \%$ від загальної кількості металургійних підприємств.

Таблиия 3

Показники діяльності металургійної промисловості за 2014-2018 р.p. [1]

\begin{tabular}{|l|c|c|c|c|c|}
\hline Показники & 2014 & 2015 & 2016 & 2017 & 2018 \\
\hline $\begin{array}{l}\text { Частка металургї̈ в загальному обсязі } \\
\text { реалізованої промислової продукції, \% }\end{array}$ & 16,6 & 15,7 & 14,8 & 15,7 & 16,2 \\
\hline $\begin{array}{l}\text { Частка металургії в загальному обсязі } \\
\text { тварного експорту, \% }\end{array}$ & 28,3 & 24,8 & 22,9 & 23,4 & 24,6 \\
\hline $\begin{array}{l}\text { Середньооблікова кількість штатних } \\
\text { працівників, тис. осіб }\end{array}$ & 272 & 244 & 218 & 207 & 190 \\
\hline $\begin{array}{l}\text { Темпи зростання прямих іноземних } \\
\text { інвестицій, \% до попереднього періоду }\end{array}$ & 65,0 & 70,3 & 101,8 & 104,9 & 101,6 \\
\hline $\begin{array}{l}\text { Частка металургійних підприємств, які } \\
\text { займалися інноваційною діяльністю, в } \\
\text { загальній кількості металургійних } \\
\text { підприємств, \% }\end{array}$ & 17,3 & 17,5 & 21,7, & 18,9 & н/д \\
\hline
\end{tabular}


Водночас, враховуючи високу залежність роботи української чорної металургії від ситуації на світовому ринку, яка, як зазначалося вище, складна й неоднозначна, закономірно постає питання про перспективи розвитку вітчизняного металургійного виробництва.

Взагалі металургійна галузь промисловості представляє собою складну, фондоємну, енергоємну, високо витратну систему. Тому, для виходу з ситуації, що склалася на сьогодні, необхідно переглянути всю систему управління нею. Перш за все, необхідним є освоєння нового сегменту світового ринку вітчизняними підприємцями. Але для цього, необхідним є залучення великої кількості інвестицій в інноваційні проекти для підвищення якості металургійної продукції та збільшення конкурентних переваг відносно світових лідерів виробництва аналогічних видів продукції. Важливим також є підвищення рівня державного фінансування таких проектів.

Ще одним пріоритетним напрямом розвитку вітчизняної металургійної галузі $\epsilon$, як зазначають експерти, відмова або скорочення обсягів продажу напівфабрикатів і сировини та перехід до експорту металопродукції 3 високою часткою доданої вартості. Однак, зазначається, що ця стратегія, за умов глобального скорочення попиту на металургійну продукції не може служити панацеєю для наших металургійних підприємств [3].

Виробництво

інноваційної металургійної продукції вимагає й вищої кваліфікації персоналу. Але, збільшення витрат на оплату праці (на сьогодні доля витрат в собівартості металургійної продукції на оплату праці операційного персоналу складає в середньому 8\%), оновлення основних фондів, впровадження новітніх технологій, в свою чергу, підвищує в рази витрати на виробництво та реалізацію металопродукції. Одним 3 дієвих виходів 3 ситуації, що склалася $\epsilon$ надання нових пільг вітчизняним металургійним підприємствам, оскільки ця галузь відіграє надзвичайно велику роль в українській економіці і при цьому вона змушена працювати за вкрай несприятливої кон'юнктури ринку [3]. Тобто подібна аргументація нерідко виступає банальним інформаційним прикриттям лобіювання корпоративних інтересів. Хоча, з іншого боку, раціональна диференціація товарної структури виробництва, у тому числі, i металургійного завжди була одним 3 надійних засобів страхування бізнесу та запоруки його ефективності.

Висновок. Аналіз діяльності металургійної галузі показав значний іiі вплив на весь промисловий комплекс України. Сучасний стан світового ринку свідчить про глобальні скорочення попиту на металопродукцію. В цих умовах приходиться функціонувати й вітчизняному металургійному виробнику. Наряду із збільшенням обсягів реалізації металопродукції на внутрішньому ринку, спостерігається зниження долі експортної продукції. Причинами цього стали: зниження рівня конкурентоспроможності вітчизняної металопродукції, підвищення ціни на неї та поява на світовому ринку нових потужних конкурентів: Китаю, Індії й Південної Кореї.

Але, вважаємо, що для подальшого розвитку металургійної галузі, необхідним $\epsilon$ : відмова або скорочення обсягів продажу напівфабрикатів і сировини та перехід до експорту металопродукції 3 високою часткою доданої вартості; пошук нових світових ринків збуту металопродукції; підвищення кваліфікації робітників зайнятих в операційній діяльності металургійних підприємств та підвищення рівня мотивації праці; отримання нових податкових та бюджетних пільг вітчизняними металургійними підприємствами. 
ПЕРЕЛІК ВИКОРИСТАНИХ ДЖЕРЕЛ

1. Державна служба статистики України [Електронний ресурс] - Режим доступу до ресурсу: http://www.ukrstat.gov.ua/.

2. Козенков Д.Є. Аналіз стану чорної металургії України: сучасні проблеми та шляхи розвитку [Електронний ресурс] / Д.С. Козенков, О. В. Цимбалюк // Ефективна економіка. - 2013. - Режим доступу до ресурсу: http://www.economy.nayka.com.ua/?op=1\&z $=2225$.

3. Кулицький С. Українська чорна металургія: стан, проблеми, перспективи [Електронний ресурс] / С. Кулицький // Україна: події, факти, коментарі. - 2016. № 5. - С. 44-65. - Режим доступу: http://nbuviap.gov.ua/ images/ukraine/2016/ukr5.pdf

4. Хижняк О.С. Сучасний стан металургійних підприємств україни: проблеми i перспективи розвитку / О.С.Хижняк // Молодий вчений, № 5 (45), 2017. - C. 762-768.

5. Worldsteel

Association [Електронний ресурс]. Режим доступу: http://www.worldsteel.org

\section{REFERENCES}

1. Derzhavna sluzhba statystyky Ukrajiny [State Statistics Service of Ukraine] URL: http://www.ukrstat.gov.ua/.

2. Kozenkov D.Je. (2013) Analiz stanu chornoji metalurghiji Ukrajiny: suchasni problemy ta shljakhy rozvytku [Analysis of the state of ferrous metallurgy in Ukraine: current problems and ways of development] Effective Economy URL: http://www.economy.nayka.com.ua/?op=1\&z $=2225$.

3. Kulycjkyj S. (2016) Ukrajinsjka chorna metalurghija: stan, problemy, perspektyvy [Ukrainian ferrous metallurgy: state, problems, prospects] Ukraine: events, facts, comments. No 5. pp. 44-65. URL: http://nbuviap.gov.ua/ images/ukraine/2016/ukr5.pdf

4. Khyzhnjak O.S. (2017) Suchasnyj stan metalurghijnykh pidpryjemstv ukrajiny: problemy i perspektyvy rozvytku [Current state of metallurgical enterprises of Ukraine: problems and prospects of development]. Young scientist, No 5 (45), pp. 762-768

5. Worldsteel Association URL: http://www.worldsteel.org

\title{
УДК 657.451
}

\section{ПІДХОДИ ДО ОБЛІКУ ЕКСПЛУАТАЦІЙНИХ ВИТРАТ ПІДПРИЕМСТВ ЗАЛІЗНИЧНОГО ТРАНСПОРТУ}

\author{
Кірдіна О.Г., д.е.н., професор, \\ Коловойда Н.В., магістр, \\ Шамрай А.С., махістр (УкрДУЗТ)
}

\begin{abstract}
Управління витратами вимагає не тільки цілеспрямованого планування та регулювання витрат на основі застосування не тільки диференційованих технічно $i$ економічно обтрунтованих норм витрат, а й аналізу, контролю їх виконання, а також постійного оновлення нормативної бази розрахунку витрат. Актуальним є визначення місия, яке займають експлуатаційні витрати в системі витрат залізничного транспорту, як вони відносяться на собівартість перевезень, встановити критеріі визначення складу робіт за господарствами, щу утворюють експлуатаційні витрати,
\end{abstract}

(C) Кірдіна О.Г., Коловойда Н.В., Вісник економіки транспорту і промисловості № 68, 2019 Шамрай А.С. 